\title{
SCALABLE EXPANSION OF MULTIPOTENT ADULT PROGENITOR CELLS AS THREE- DIMENSIONAL CELL AGGREGATES
}

\author{
${ }^{1,2}$ Subramanian $K^{\#,},{ }^{2,3}$ Park $Y^{\#},{ }^{2,4}$ Verfaillie CM, ${ }^{1,2} \mathrm{Hu}$ WS*
}

${ }^{1}$ Department of Chemical Engineering and Materials Science, University of Minnesota, Minneapolis, MN 55455-0132 USA, ${ }^{2}$ Stem Cell Institute, University of Minnesota, Minneapolis, MN 55455, USA, Department of Biomedical Engineering, University of Minnesota, Minneapolis, MN 55455, USA, ${ }^{4}$ Interdepartmental Stem Cell Institute Leuven, Catholic University Leuven, Belgium

\# Authors contributed equally to this work and should be considered co-first authors.

*Corresponding Author

Wei-Shou $\mathrm{Hu}$

Address: 421 Washington Avenue SE

Minneapolis, MN 55455-0132 USA

Phone: (612) 626-7630

Fax: (612) 626-7246

Email: acre@cems.umn.edu

Additional Supporting Information may be found in the online version of this article.

(C) 2010 Wiley Periodicals, Inc.

Received March 24, 2010; Revised August 5, 2010; Accepted August 9, 2010 


\section{Abstract}

Many applications of stem cell technologies require a large quantity of cells for which scalable processes of cell expansion and differentiation are essential. Multipotent adult progenitor cells (MAPCs) are adult stem cells isolated from the bone marrow with extensive self-renewal and broad differentiation capabilities. MAPCs are typically cultured surface adherent (2D) and at low cell density, making the large surface required for cell expansion a hindrance for many applications. This study demonstrates that MAPCs can be cultivated as aggregates in an undifferentiated state for at least 16 days, as levels of a number of transcripts, including Oct4, remained similar, Oct4 protein was unchanged, and differentiation to neural progenitor, endothelial cell and hepatocyte like cells was retained. Cultivation of these aggregates in stirred bioreactor lead to a 70-fold expansion in six days with final cell densities of close to $10^{6} / \mathrm{ml}$. Importantly, the MAPC aggregates recovered from stirred bioreactors could be differentiated to hepatocyte-like cells that expressed albumin, alpha-1-antitrypsin $(A A T)$, and tyrosine amino transferase $(T A T)$ transcripts and also secreted albumin and urea. This method of scalable expansion combined with differentiation of MAPCs can potentially be used for generating large numbers of MAPC and MAPC-derived differentiated cells.

KeyWords: Multipotent Adult Progenitor CELLS, 3D AgGregates, StirRed Suspension Culture
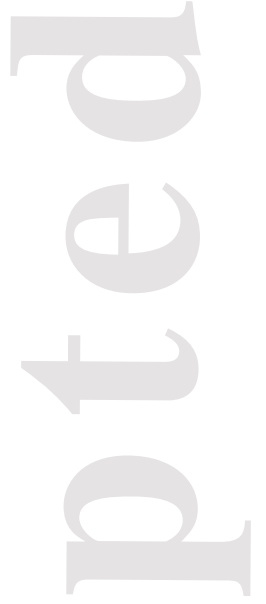


\section{INTRODUCTION}

With the growing potential of stem cells for applications in cellular therapy and drug toxicity screening, there is an increasing need for the design of robust bioprocesses for their scalable expansion and differentiation. The widespread use and extensive experience with stirred suspension culture systems for microbial and mammalian cell culture, makes them an attractive option as a large scale culture system for stem cell technologies. Stirred suspension cultures provide a more homogenous culture environment along with the capability for online monitoring and control of physicochemical parameters such as nutrient and cytokine concentrations, oxygen and $\mathrm{pH}$. Moreover, cell concentrations of $10^{6}-10^{7}$ cells $/ \mathrm{ml}$ can be attained in conventional suspension bioreactors. High cell density culture in the bioreactors and minimal need of manual intervention results in a more costeffective bioprocess. Thus, to meet the clinical need of $\sim 10^{9}-10^{10}$ cells per treatment, bioreactors of working volumes in the range of $100 \mathrm{ml}$ to a few liters are sufficient. Further, as these culture systems are already commonly used in the conventional cell culture industry, adapting them for use in development of stem cell related bioprocesses would be straightforward and thus minimize design costs.

Suspension culture has been used in the expansion and differentiation of murine and human embryonic stem cells (ESC) by cultivating them as aggregates or on microcarriers (Abranches et al. 2007; Cameron et al. 2006; Cormier et al. 2006; Dang et al. 2004; Fok and Zandstra 2005; Krawetz et al. 2009; Lock and Tzanakakis 2009; Oh et al. 2009; zur Nieden et al. 2007). It is also possible to culture adult stem cells, such as hematopoietic stem and progenitor cells (Li et al. 2006), neural stem cells (Gilbertson et al. 2006) and mesenchymal stem cells (MSCs) (Frauenschuh et al. 2007; Yu et al. 2009) in suspension. Most studies involving MSCs have either been with cells seeded on microcarriers (Frauenschuh et al. 2007) or embedded within 3D polymeric scaffolds (Zhao and Ma 2005). In a recent study, the culture of MSCs as multi-cellular three-dimensional (3D) aggregates was demonstrated as 
another mode for culture in suspension (Frith et al. 2009). Aside from the obvious advantage of largescale cell production in a spinner culture system, there is also increasing evidence of a significantly better recapitulation of the in-vivo phenotype and biological response in 3D aggregates than in traditional two-dimensional (2D) monolayer culture methods. This is thought to be due to differences in cell-cell and cell-matrix interactions, cell shape, spatial gradients, leading to differences in gene and protein expression. Thus, the potential applications of these 3D systems also extend to developing 'biomemtic' 3D tissues/organoids and as a in-vitro model for studying differentiation, organogenesis, migration, tumor biology, and in high-throughput drug screening (Griffith and Swartz 2006; Keller et al. 2006; Liu et al. 2009; Ong et al. 2009; Pampaloni et al. 2007; Yamada and Cukierman 2007).

Multipotent Adult Progenitor Cells (MAPC) (Breyer et al. 2006; Jiang et al. 2002; Reyes et al. 2001) are isolated from the bone marrow with extensive proliferation capability and differentiation potential into multiple cell types including the endothelial and smooth muscle cells (Luttun et al. 2006), and hepatocytes (Schwartz et al. 2002), among others. When isolated from rodent bone marrow (mouse and rat), we have found that MAPC express high levels of Oct4 at the mRNA and protein level, but do not express Nanog or Sox2. However, they also express transcription factors found in primitive endoderm and the recently described Xen-P cells (Debeb et al. 2009; Galat et al. 2009), such as Sox7, Sox17, Foxa2, Gata4, and Gata6 (Ulloa-Montoya et al. 2007).

Since the initial isolation of MAPC, other adult stem cells with similar broader differentiation potential, have been isolated (Anjos-Afonso and Bonnet 2007; Beltrami et al. 2007; D'Ippolito et al. 2004; Guan et al. 2006; Gupta et al. 2006; Kogler et al. 2004; Kucia et al. 2006; Ratajczak et al. 2008; Yoon et al. 2005). The relationship between these different stem cell populations is not understood yet. Whether they exist in vivo or are obtained as a consequence of in-vitro reprogramming or selection is not clear either. Nevertheless, obtaining cells with broad differentiation capacity from somatic tissues, without the need for addition of exogenous genes, may offer an alternative source of cells to study or 
compare self-renewal, differentiations and reprogramming mechanisms, and for potential cell therapy and drug toxicity screening applications.

MAPC have traditionally been cultured at low density $\left(200-300\right.$ cells $\left./ \mathrm{cm}^{2}\right)$ on tissue culture dishes, as it was believed that the higher-density may result in differentiation and loss of potency, as has been suggested for MSC (Javazon et al. 2004). Here, we explored culturing rat bone marrow derived MAPC as $3 \mathrm{D}$ cell aggregates amenable to suspension culture and scalable expansion in bioreactors. We report the self-assembly of MAPC into 3D cell aggregates that maintain differentiation potency over at least sixteen days, and their scalable expansion in 3D suspension culture, while retaining the potential for liver differentiation application. The principles developed in this study may also be applicable for the scalable growth and differentiation of MSCs and other stem and progenitor cells.

\section{MATERIALS AND METHODS}

ESTABLISHMENT AND MAINTENANCE OF RAT MAPC LINES

Two rat MAPC lines were used in this study. The isolation of rat MAPC lines has been previously described (Breyer et al. 2006; Ulloa-Montoya et al. 2007). Briefly, rat MAPC lines were isolated from the tibia and femur of 4 week old female rat (Fischer). Cells were plated on 6 well tissue culture plates in MAPC medium at $6 \times 10^{6} /$ well and cultured in a humidified incubator at $37^{\circ} \mathrm{C}$ with $5 \%$ oxygen and $5.5 \% \mathrm{CO}_{2}$. After 4 weeks of culture, hematopoeitic cells were removed using magnetic microbeads against CD 45 and Ter 119 (Miltenyi Biotec) and the remaining cells were seeded into 96 well plates at 5 cells/well. Cells with small size and spindle shaped morphology that appear in the wells were subsequently picked and screened for MAPC phenotype (expression of Oct4, Rex1 and CD31) and trilineage differentiation potential (Breyer et al. 2006). The established MAPC cell lines were maintained in MAPC medium at $37^{\circ} \mathrm{C}$ in a $5 \%$ oxygen and $5-6 \% \mathrm{CO}_{2}$ incubator at a starting cell density of 300 cells $/ \mathrm{cm}^{2}$ and passaged using $0.05 \%(\mathrm{w} / \mathrm{v})$ Trypsin-EDTA ( $5 \mathrm{mg} / \mathrm{l}$ Cellgro) every two days (Breyer et al. 2006). 
MAPC MEDIA

MAPC medium consisted of a basal medium that was a 60/40 (v/v) mixture of low glucose Dulbecco's Modified Eagle media (DMEM) (Gibco, USA) and MCDB-201 (Sigma) supplemented with 0.026 $\mu \mathrm{g} / \mathrm{ml}$ ascorbic acid 3-phosphate (Sigma), linoleic acid bovine serum albumin (LA-BSA, Sigma)) (final concentrations of $10^{3} \mu \mathrm{g} / \mathrm{ml} \mathrm{BSA}$ and $8.13 \mu \mathrm{g} / \mathrm{ml}$ linoleic acid), insulin-transferrin-selenium (ITS, Sigma) (final concentration $10 \mu \mathrm{g} / \mathrm{ml}$ insulin, $5.5 \mu \mathrm{g} / \mathrm{ml}$ transferrin, $0.005 \mu \mathrm{g} / \mathrm{ml}$ sodium selenite), $0.02 \mu \mathrm{g} / \mathrm{ml}$ dexamethasone (Sigma), $4.3 \mu \mathrm{g} / \mathrm{ml} \beta$-mercaptoethanol and 2\% (v/v) qualified fetal bovine serum (Hyclone). Complete MAPC medium also contained three growth factors: human platelet derived growth factor (PDGF-BB, R\&D) $(10 \mathrm{ng} / \mathrm{ml})$, mouse epidermal growth factor (EGF, Sigma) (10 ng/ml) and mouse leukemia inhibitory factor (LIF) (10 $30^{3}$ Units/ml) (Chemicon, ESGRO). All media used were also supplemented with $100 \mathrm{IU} / \mathrm{ml}$ penicillin and $100 \mu \mathrm{g} / \mathrm{ml}$ streptomycin (Gibco).

\section{STATIC PLATE CULTURE OF MAPC AGGREGATES}

MAPC aggregates were formed from single cells of MAPCs using the hanging drop method (Kurosawa et al. 2003) or the forced aggregation method ( $\mathrm{Ng}$ et al. 2005). Briefly, in the hanging drop method 300-3000 single cells were suspended in a single drop of medium hanging on an inverted plastic surface (Nunc) containing 60 small drops of cells and medium and each were allowed to agglomerate into individual aggregates. In the forced aggregation method, cells in suspension were placed in a well of an ultra-low attachment round bottomed 96 well plate (Corning) and centrifuged for $4 \mathrm{~min}$ at $1500 \mathrm{rpm}$, to allow cells to settle to the bottom of the well. Unless otherwise specified the settled cells were grown in a $37^{\circ} \mathrm{C}$ incubator at $5 \%$ oxygen to allow for aggregates to form over time. For static plate culture, MAPC aggregates were formed using either of the two methods. When formed by the hanging drop method, the MAPC aggregates from day 4 were cultured in ultra-low attachment 24 well plates (Corning) with 10 aggregates/wells. Forced aggregation method aggregates were formed and cultured for the entire culture period in 96 well plates. In both cases, MAPC medium and 5\% oxygen conditions were used with 50\% medium changes every two days. MAPC aggregates were also plated in differentiation conditions (MAPC medium without LIF, PDGF and EGF and 21\% oxygen) for the same time period as maintenance cultures.

SUSPENSION FLASK CULTURE OF MAPC AGGREGATES

Prior to suspension culture, MAPC aggregates were formed using the forced aggregation method in static culture for two days. Aggregates were then transferred to a $250 \mathrm{ml}$ spinner flask at an initial cell concentration of 50,000 cells $/ \mathrm{ml}$ and the culture was stirred at $70 \mathrm{rpm}$ and kept inside a $37^{\circ} \mathrm{C}$ incubator with $5 \%$ oxygen control. 


\section{DISSOCIATION OF MAPC AGGREGATES}

To dissociate the MAPC aggregates into single cells, the aggregates were washed once with PBS and suspended in pre-warmed $0.05 \%$ (w/v) Trypsin-EDTA for $15-20 \mathrm{~min}$ in a $37^{\circ} \mathrm{C}$ water bath. The aggregates-cell suspension was pipetted a few times and subsequently incubated for an additional 5 min in the water bath until the aggregates were dissociated into single cells, as observed under the microscope.

RNA ISOLATION AND QUANTITATIVE REAL TIME POLYMERASE CHAIN REACTION (RT-QPCR)

Total RNA was isolated from rMAPC cell lysates using RNAeasy microkit (Qiagen) according to instructions provided in the kit. cDNA was synthesized from the extracted RNA using the Superscript III reverse transcriptase (Invitrogen) method. The PCR reaction mix consisted of cDNA samples, SYBR Green Mix PCR reaction buffer (Applied Biosystems) and primers ( $5 \mu \mathrm{M}$ stocks, sequences listed in table 1). The RT-qPCR reaction was run on a Realplex mastercycler (Eppendorf) using the following program: $50^{\circ} \mathrm{C}$ for $2 \mathrm{~min}, 95^{\circ} \mathrm{C}$ for $10 \mathrm{~min}$, and 40 cycles at $95^{\circ} \mathrm{C}$ for $15 \mathrm{sec}$ and $60^{\circ} \mathrm{C}$ for 1 min followed by a dissociation protocol to obtain a melting curve. Transcript abundance relative to GAPDH was expressed as $\log _{2}$ (Transcript expression relative to GAPDH) and calculated as $\Delta \mathrm{Ct}$ which is $\mathrm{Ct}($ gene of interest)-Ct(GAPDH) and Transcript abundance in sample relative to day 0 was expressed as the $\log _{2}$ (Transcript expression level relative to day 0 ) and calculated as $\Delta \mathrm{Ct}$ (day 0 )$\Delta \mathrm{Ct}$ (day of sample). Student's t-test with a p-value cut off of 0.05 was used to call for any significant difference in expression between the different samples.

\section{INTRACELLULAR STAINING FOR OCT4 BY FLOW CYTOMETRY}

Cells harvested by trypsinization were washed with and suspended in PBS with 3\% (v/v) serum at 100,000 cells per FACS tube. After fixing with 4\% paraformaldehyde for 15-20 min, and blocking for $1 \mathrm{hr}$ in SAP buffer (PBS with $0.1 \%(\mathrm{w} / \mathrm{v})$ saponin and $0.05 \%(\mathrm{w} / \mathrm{v})$ sodium azide) supplemented with $10 \%$ donkey serum, cells were incubated for $1 \mathrm{hr}$ with $1 \mu \mathrm{g} / \mathrm{ml}$ Oct3/4 antibody (Santa-Cruz, N19) or Goat IgG isotype control (Jackson Immunoresearch) diluted in SAP buffer before incubating with Cy5 labeled anti-goat IgG (Jackson Immunoresearch, 1:500 in SAP buffer) for 30 min. Finally, cells were 
washed, filtered and re-suspended in $500 \mu \mathrm{l}$ PBS for flow cytometry analysis using FACS Calibur (Becton Dickinson).

IN-VITRO DIRECTED DIFFERENTIATION FOR EVALUATING MAINTENANCE OF DIFFERENTIATION POTENCY OF $M A P C$

\section{Neuroectodermal differentiation}

rMAPC were cultured at 1500 cells $/ \mathrm{cm}^{2}$ on $0.1 \%$ gelatin coated $\mathrm{T} 75$ flasks in neural differentiation medium that consisted of 50\% (v/v) DMEM/F12 (Invitrogen) and 50\% (v/v) neurobasal A medium (Invitrogen) supplemented with N2 plus supplement (R\&D systems), B27 (Invitrogen), $4.3 \mu \mathrm{g} / \mathrm{ml} \beta$ mercaptoethanol, $0.3 \mathrm{mg} / \mathrm{ml}$ glutamine (Invitrogen) for 2 days. On Day 2, the medium was completely replaced with Euromed-N medium (Annovum/Euroclone) supplemented with $0.3 \mathrm{mg} / \mathrm{ml}$ glutamine, N2 plus supplement, $4.3 \mu \mathrm{g} / \mathrm{ml} \beta$-mercaptoethanol and growth factors: basic fibroblast growth factor (R\&D, bFGF) (10 ng/ml) and EGF (Sigma) (10 ng/ml). On Day 6, cells were trypsinized and re-plated in $0.1 \%$ gelatin coated T25 flasks in neural differentiation medium supplemented with bFGF (10ng/ml) and EGF (10ng/ml). Differentiations were continued for fourteen days in 5\% oxygen conditions with media change every two days.

\section{Endothelial differentiation}

rMAPC were cultured on fibronectin $(100 \mathrm{ng} / \mathrm{ml})$ coated 24 well plates at a cell density of 45,000 cells $/ \mathrm{cm}^{2}$ in MAPC media. After about $16 \mathrm{hr}$, the medium was completely replaced with endothelial differentiation medium whose composition was the same as MAPC medium except that the three growth factors were absent, dexamethasone was at $0.4 \mu \mathrm{g} / \mathrm{ml}$, and that $10 \mathrm{ng} / \mathrm{ml} \mathrm{recombinant} \mathrm{human}$ VEGF (R\&D) was added. Differentiations were continued for twenty days in $21 \%$ oxygen conditions with $50 \%$ media change every two days.

\section{Hepatocyte differentiation}

rMAPC were cultured on matrigel $(2 \%, \mathrm{BD})$ coated wells of a 24 well plate at a starting cell density of 50,000 cells $/ \mathrm{cm}^{2}$ in MAPC medium until a confluence of $80-90 \%$ is reached. Subsequently, the 
expansion medium was completely replaced with differentiation basal medium whose composition was the same as MAPC medium except that ITS and LA-BSA were at $25 \%$ of the amount in MAPC medium, dexamethasone was at $0.4 \mu \mathrm{g} / \mathrm{ml}$ and the three protein factors and serum were absent. Furthermore, additional protein factors were added as described below. The cytokines and growth factor supplements were added as follows: (i) Day 0: Activin A at $100 \mathrm{ng} / \mathrm{ml}$ and Wnt3a at $50 \mathrm{ng} / \mathrm{ml}$ (ii) Day 6: bFGF at $10 \mathrm{ng} / \mathrm{ml}$ and BMP4 at $50 \mathrm{ng} / \mathrm{ml}$ (iii) Day 10: FGF8b at $25 \mathrm{ng} / \mathrm{ml}$, aFGF at 50 $\mathrm{ng} / \mathrm{ml}$ and FGF4 at $10 \mathrm{ng} / \mathrm{ml}$ (iv) Day 14: $\mathrm{HGF}$ at $20 \mathrm{ng} / \mathrm{ml}$ and Follistatin at $100 \mathrm{ng} / \mathrm{ml}$. Differentiations were carried out for twenty days in $21 \%$ oxygen conditions with $50 \%$ media change, corresponding to the differentiation stage, every two days. On days $0,6,10$, and 14 , complete medium was replaced with fresh medium with supplements for the ensuing differentiation stage.

\section{TIME LAPSE MICROSCOPY}

MAPCs were seeded at 1000 cells/well in ultra-low attachment round bottom 96 well plates (Corning). The initial aggregation of the cells was observed by microscope (Leica) located in an incubation system of $37^{\circ} \mathrm{C}, 5 \% \mathrm{CO}_{2}$, and $5 \%$ or $21 \% \mathrm{O}_{2}$ for 48 hours. Images of cells undergoing aggregation were taken every $4 \mathrm{~min}$ over $48 \mathrm{hr}$. The size of aggregates was determined from an average of three or more wells each containing a single aggregate.

TRANSMISSION ELECTRON MICROSCOPY

Cells aggregates were washed thrice with $0.1 \mathrm{M}$ cacodylate buffer and fixed in $2.5 \%$ glutaraldehyde and $0.1 \mathrm{M}$ sodium cacodylate buffer $(\mathrm{pH} 7.2$ ) for $40 \mathrm{~min}$. After post-fixation in 1\% osmium tetroxide and $0.1 \mathrm{M}$ of cacodylate buffer, the samples were dehydrated in graded series of ethanol folloed by propylene oxide treatment, and embedded in epoxy resin. Ultrathin sections were cut, stained with uranyl acetate and lead citrate, and examined using a JEOL 1200 EXII electron microscope at the Characterization facility at University of Minnesota.

E-CADHERIN STAINING

Cells aggregates were fixed in 4\% paraformaldehyde for $30 \mathrm{~min}$ and washed with PBS. The samples were incubated in 5\% sucrose in PBS overnight and supercooled with isopentane before freezing in OCT and obtaining sections. $\mathrm{H}_{2} \mathrm{O}_{2}$ was used to inhibit endogenous peroxidase and incubated with fetal bovine serum (FBS) to reduce non-specific binding. Cells were then incubated with anti-E-cadherin (BD) antibody or with isotype-matched negative control antibodies (mouse IgG2a) and then subsequently visualized using EnVision-Peroxidase with DAB substrate (Dako).

CELL VIABILITY STAINING

The "live/dead viability/cytotoxicity kit" (Invitrogen) was used to stain cells in the aggregates with calcein and ethidium. Component B was added first to DPBS (1:1000) and then component A was added to DPBS with component B (1:2000). Cells were incubated with the staining solution for 15-30 min at $37^{\circ}$ C. Cells were washed once with PBS and observed under inverted fluorescent microscope 
(Axiovert 200, Zeiss). Live and dead cells appear as green and red respectively. Validation of the protocol to detect dead cells was confirmed with the red stain observed in cells in aggregates that were treated with $0.1 \%(\mathrm{w} / \mathrm{v})$ saponin (to induce permeabilization based cell death) for $30 \mathrm{~min}$ prior to the staining protocol.

\section{CELL CYCLE ANALYSIS}

Cells were fixed in $80 \%$ ethanol and stored at $-20^{\circ} \mathrm{C}$. Fixed cells were washed twice with PBS and then stained in PBS with $50 \mu \mathrm{g} / \mathrm{ml}$ propidium iodide and $0.1 \mathrm{mg} / \mathrm{ml} \mathrm{RNAse} \mathrm{overnight} \mathrm{at} 4^{\circ} \mathrm{C}$. After washing cells were filtered and re-suspended in $500 \mu 1$ PBS for flow cytometry analysis using FACS Calibur.

\section{RESULTS}

\section{MAPC self-assemble into cell aggregates}

We evaluated aggregate formation from single suspensions of MAPCs using two methods known as the hanging drop and the forced aggregation methods. rMAPC were inoculated at a starting cell concentration ranging from $3000-30,000$ cells $/ \mathrm{ml}$ (or 300 to 3000 cells per well or per drop) and single aggregate from each drop or well was readily formed. Aggregates were formed in complete MAPC medium or MAPC medium without LIF, PDGF and EGF (differentiation medium) in $5 \%$ or $21 \%$ oxygen. For all studies, two rat MAPC lines were tested at least in triplicates. Aggregates formed in complete MAPC medium with 5\% oxygen, on day 4, expressed Oct4, Rex1, CD31 and HNF3b transcripts at levels comparable to the parent MAPC-line cultured on 2D surface (5\% oxygen), but not $A f p$, a gene we have shown to be rapidly up-regulated when MAPC differentiate spontaneously (Figure 1a). In addition, Oct 4 protein expression was maintained in these aggregates as shown by flow cytometry (Figure 1b). In contrast, aggregates formed in MAPC medium at $21 \%$ oxygen, were differentiating, as they expressed a 32 fold more Afp transcript (Figure 1c) and the fraction of cells expressing Oct4 protein decreased by about $50 \%$ (Figure 1d). Formation of aggregates in MAPC medium without LIF, PDGF and EGF even with a 5\% oxygen resulted in a 21 fold decrease in Oct4 transcript (Figure 1c) with only about $4 \%$ of the cells expressing Oct4 protein (Figure 1d). Thus, both high ambient oxygen concentrations and removal of LIF, PDGF and EGF negatively affected the Oct4 expression during aggregate formation, and resulted in differentiation. Cells in MAPC aggregates formed under $5 \% \mathrm{O}_{2}$ in complete MAPC medium could also be trypsinized to single cell suspensions and re-cultivated on 2D surface exhibiting typical MAPC proliferation profiles and phenotype (Supplementary Figure 3).

\section{Characterization of the MAPC aggregates and their formation}

Four days after cell seeding, the MAPC aggregates had barely distinguishable cell-cell boundaries (Figure 2a). Time-lapse microscopy was used to visualize the process of aggregate formation over a period of $48 \mathrm{hr}$. After the centrifugal settling to the bottom of a well, single cells clustered together to an average size of $540 \mu \mathrm{m}$. Subsequent compaction led to the cell aggregates of about $250 \mu \mathrm{m}$ in size. The aggregate then increased in size to about $460 \mu \mathrm{m}$ by $48 \mathrm{hr}$ after the initial agglomeration (Figure $2 b) .10$ aggregates were dissociated by trypsinization every day for cell counting. The average number of cells in each aggregate increased from 1000 to 17,758 cells per aggregate $(668 \pm 19 \mu \mathrm{m}$, mean and $\mathrm{SD}$ of ten aggregates) in four days (Figure 2c).

The population doubling time during the four days of formation was about $23 \mathrm{hr}$, slower than that seen when cultivated on a 2D surface (12-14 hr). The doubling time between Day 1 to 3 is approximately 12 $\mathrm{hr}$. Between Day 3 and Day 4, a slow down in cell growth is observed (Figure 2c). Cell cycle analysis done by flow cytometry indicated that a larger fraction $(60 \%)$ of MAPC in aggregates (Day 4) were in G0/G1, in comparison to 2D surface culture (40\%) (Supplementary Figure 4). TEM analysis of the 
aggregates showed tightly packed cells with high nucleus to cytoplasm ratio, a characteristic of MAPCs. Tight junctions were seen at cell-cell boundaries (Figure 2d). Immunohistochemistry demonstrated that MAPC in aggregates expressed the cell membrane associated adhesion protein Ecadherin (Figure 2e).

\section{MAPC aggregates retain differentiation potential in culture}

We next examined whether MAPC aggregates could be maintained in culture for an extended periods of time without losing their characteristic phenotype. MAPC aggregates were allowed to form for four days and were subsequently kept for another sixteen days in complete MAPC culture medium or MAPC medium without LIF, PDGF and EGF with 50\% medium change every two days. RT-qPCR for Oct 4 and $A f p$ transcript expression was used to evaluate the undifferentiated status of culture. MAPC aggregates maintained the level of Oct4 transcript without increase in $A f p$ transcript level. However, for MAPC aggregates cultured in MAPC medium without LIF, PDGF and EGF (and with 21\% oxygen), expression of Oct4 transcript decreased and the expression of $A f p$ transcript progressively increased with time (Figure 3a, 3b). During the sixteen days of culture in complete MAPC culture medium, cell proliferation occurred, as noted by the increase of the aggregates size or budding off of small groups of cells from the single MAPC aggregate to form smaller aggregate (Supplementary Figure 5).

After sixteen days in culture, the MAPC aggregates were dissociated into single cells by trypsinization and the expression of Oct4 protein was evaluated by flow cytometry (Figure 3c, 3d). The fraction of cells that continued to express Oct 4 protein at the end of the sixteen-day culture (79\% for one MAPC line and $78 \%$ for the other MAPC line) was similar to 2D monolayer cultures and MAPC aggregates on Day 0 (Figure 1b). These cells were re-expanded and after two passages of expansion in $2 \mathrm{D}$ surface at low cell density, aggregate-derived cells were used for directed differentiation towards endothelial, hepatic and neural progenitor lineages and the differentiations were compared to that of MAPC maintained for the whole period at low cell density in 2D surface culture. As can be seen in Figure 4, no significant differences in differentiation could be detected (student's t-test, with a $p$ value cutoff of 0.05). During neural differentiation, similar increases in levels of expression of Sox2, Pax6 and Nestin transcripts were observed in both cells cultured as aggregates for sixteen days followed by 2D surface culture, as cells maintained in 2D surface culture for the whole time period (Figure 4a). Similar results were observed in the endothelial differentiation as demonstrated by the increased expression of Flk-1, Ve-Cadherin, $v W F$, Enos transcripts (Figure $4 \mathrm{~b}$ ), and in the hepatocyte lineage differentiation, shown by the increase in expression of Afp, Albumin, Aat and Tat transcripts (Figure 4c). Thus, MAPC can be cultured as aggregates for at least sixteen days with differentiation potential for all three lineages.

\section{Expansion of MAPC as aggregates in suspension culture}

We also explored if MAPC can be expanded as aggregates in suspension culture. The cultures were repeated three times with one MAPC cell line (Figure 5) and twice with another MAPC line (Supplementary Figure 6). MAPC aggregates were formed under static culture conditions for two days and then seeded into a $250 \mathrm{ml}$ spinner flask with a $100 \mathrm{ml}$ working volume. During the first two days of static culture (day -2 to day 0 ) cell concentration grew from $10^{4}$ to $5 \times 10^{4}$ cells $/ \mathrm{ml}$. From day 0 to day 2 of suspension culture, an additional six-fold increase in cell number was seen. On day 2 of suspension culture, cell aggregates were harvested and the cell concentration in the flask was reduced to $50 \%$ and $50 \mathrm{ml}$ of fresh medium was added. At the end of six days of culture, a final cell concentration of $7 \times 10^{5}$ cells $/ \mathrm{ml}$, equivalent to 70 fold expansion, was obtained for rMAPC-1 (Figure 5a). Similar cell concentration was obtained on Day 4 of spinner expansion culture of the other rat MAPC line as well (Supplementary Figure 6a). 
Staining with the LIVE/DEAD cytotoxicty kit (Molecluar Probes) demonstrated that the cells within the aggregates (day 4) retained high viability (Figure 5b). The transcript levels of key MAPC genes such as Oct4, Rex1, CD31, Sall4 and differentiation marker Afp of Day -2 (cells from 2D maintenance culture), Day 0 (cells after $48 \mathrm{~h}$ aggregation in wells) and Day 2 and 4 (aggregates in spinner cultures) were assessed by RT-qPCR. No differences in Oct4, Rex1, CD31 and Sall4 transcripts could be detected, and no increase in AFP expression was observed (Figure 5c, Supplementary Figure 6b). In addition, the expression of Oct4 protein was also evaluated by flow cytometry. The fraction of cells that continued to express Oct 4 protein at the end of spinner flask culture (day 4, 77\% for one MAPC line and $74 \%$ for the other MAPC line) and the control 2D surface culture (day4, 79\%) was similar (Figure 5d, Supplementary Figure 6c). Thus, the cells in stirred suspension culture could be expanded without obvious signs of differentiation.

To evaluate whether MAPC aggregate cultivated in spinner continued to have similar differentiation potential, Day 0, 2 and 4 aggregates were subjected to hepatocyte differentiation as aggregates in static culture on 24 well ultra-low attachment plates using a protocol previously developed by our lab (manuscript submitted). Differentiation towards the hepatocyte lineage was chosen because in vitro drug testing applications require large quantity of hepatocytes. We evaluated the extent of upregulation of hepatocyte-specific transcripts by RT-qPCR at the end of twenty days of differentiation of cell aggregates collected at different points of spinner culture, over the expression levels in the starting cell aggregates, in each case. We demonstrate that the MAPC aggregates (from Day 0, 2 and 4) were differentiated to 'hepatocyte-like' cells as shown by the up-regulation of hepatocyte specific transcripts Afp, Albumin, Aat and Tat (Figure 5e). The level of up-regulation of these genes was similar for all starting cell populations. In addition, differentiated cells from each of the differentiations also secreted albumin at $0.7-0.8 \mathrm{pg} / \mathrm{cell} / \mathrm{day}$ or about $10 \%$ of the level secreted by adult rat hepatocytes, and urea was secreted at 4-7 $\mu \mathrm{g} / \mathrm{day}$. Thus, the cells expanded in the spinner culture can also be used for generating large numbers of 'hepatocyte-like' cells.

\section{DISCUSSION}

Stem cells offer great potential for regenerating and replacing dysfunctional tissues, and as tools for research on normal differentiation processes, models of disease, and for drug toxicity testing. Because of their importance in regenerative medicine and research, there is an increasing interest in the development of robust bioprocesses for generating large quantities of stem cells and their differentiated derivatives. Several bioreactor designs have been tested for cultivation of different stem cell types (reviewed extensively in (Kehoe et al. 2009; King and Miller 2007; Kirouac and Zandstra 2008).) Among the different bioreactors, stirred tank based designs have been most widely used for the cultivation of mammalian cells because of the ease in maintaining homogenous environment with online process monitoring and control. Furthermore, extensive experience and knowledge on their design and operation has accumulated in the past that will be useful in the scale up of stem cell bioprocesses.

MAPC's capability of extensive self-renewal and multi-lineage differentiation ability to lineages of cell three germ layers (Breyer et al. 2006; Luttun et al. 2006; Schwartz et al. 2002; Ulloa-Montoya et al. 2007) makes them an excellent model for study of developmental processes. Subsequent to the initial isolation of MAPCs, we have further optimized a robust isolation procedure to obtain multiple rat MAPC lines, from fetal and adult bone marrow, with very similar phenotype and differentiation capabilities (Subramanian et al.). However, the need for low-density maintenance of MAPCs constitutes a technical hurdle for potential clinical translation. We recently found that MAPCs can be cultured at higher cell densities $\left(1000 \mathrm{cells} / \mathrm{cm}^{2}\right.$, with a cell concentration of $\left.\sim 10^{5} / \mathrm{ml}\right)$ without change 
in multi-lineage differentiation capability when cultivated in 2D under 5\% oxygen (Park et.al, manuscript submitted). This prompted us to evaluate the possibility of growing MAPC as aggregates for suspension culture in a stirred tank. We adopted the hanging drop (Kurosawa et al. 2003) and forced aggregation ( $\mathrm{Ng}$ et al. 2005) methods because of their ease of use and the high-efficiency of aggregate formation. Both methods gave relatively uniform sizes of aggregates and allowed cells to continue to proliferate during aggregate formation (Kelm et al. 2003; Kurosawa 2007). This capability of growing as aggregates has been seen in multiple rat MAPC lines from independent isolations. The aggregates appeared tightly packed, expressing cell membrane associated E-Cadherin. Fibronectin, an extracellular matrix protein, was expressed at higher transcript levels in 3D aggregates than in 2D MAPCs cultivated on fibronectin coated dishes (supplementary Figure 2a). In addition, the MAPCs, cultivated on plates coated with conditioned medium from the aggregate (3D) culture, expanded to similar cell numbers as those cultivated on fibronectin coated plates. In contrast, a significantly lower cell number was obtained on plates coated with conditioned medium from 2D surface culture or on plates without any coating (supplementary Figure 2b). This enhanced cell-cell and cell-matrix interactions seen in 3D aggregates may also help in better recapitulating the native microenvironment for applications in the study of development and morphogenesis, drug screening, stem cell differentiation, tissue engineering and tumor biology, in addition to their applicability in scalable suspension cultures. As an illustration, we observe improved efficiency and maturation of hepatocyte differentiation from 3D MAPC aggregates as compared to 2D MAPC surface culture (manuscript in preparation).

MAPC express Oct4 protein in the nucleus (Breyer et al. 2006), a transcription factor expressed in morula, inner cell mass (ICM), epiblast and hypoblast, as well as in embryonic stem cells (ESC) and male germline stem cells (Guan et al. 2006; Niwa 2007; Ralston and Rossant 2005). Oct4 is known to crucial for the pluripotent nature of cells in the ICM, epiblast and ESC. In addition to MAPC, other bone marrow derived stem or progenitor cells have also been reported to express Oct $4 \mathrm{mRNA} /$ protein (D'Ippolito et al. 2004; Kucia et al. 2006; Pochampally et al. 2004). When cultured without LIF, MAPC rapidly lose Oct4 and begin to show signs of differentiation with rapid up-regulation of Afp, expressed in the visceral endoderm (manuscript in preparation). In addition to Oct4, MAPC also express other ESC transcription factors including Sall4 and Rexl as well as transcription factors of primitive endoderm/visceral endoderm/definitive endoderm such as Hnf3b, Gata4, Gata6, Sox7, and Sox17 (Ulloa-Montoya et al. 2007). Aggregates formed in complete MAPC medium and 5\% oxygen and maintained in either static or suspension culture expressed Oct4, Sall4, Rex1, CD31, GATA6, GATA4, Sox7, Sox17 and Hnf3b transcripts at levels expressed in MAPC grown in 2D, but no Afp transcripts. MAPC aggregates also expressed similar levels of Oct4 protein that in 2D. Other pluripotent stem cells including mouse ESCs have also been cultured in suspension as undifferentiated aggregates in a medium supplemented with LIF (Cormier et al. 2006). For ESC, withdrawal of LIF from the medium results in differentiation of ESC into embryoid bodies (EBs) (Kurosawa 2007; Kurosawa et al. 2003). In addition to the requirement of LIF (and EGF, PDGF), we found 5\% oxygen is favorable for maintaining and expanding undifferentiated MAPC as aggregates or in 2D surface culture. This is consistent with the findings that culturing hematopoietic stem and progenitor cells (HSCs) at low oxygen tension (1-5\%) maintained the earliest progenitor cells, while increase in oxygen tension resulted in differentiation into more mature cell types (Hevehan et al. 2000; Mostafa et al. 2000). Likewise, low oxygen tension facilitated the expansion and maintenance of stem cell genes in MSCs as well (D'Ippolito et al. 2006; Grayson et al. 2006).

While the phenotype of MAPC in aggregates was mostly similar to that of MAPC in 2D surface culture, we noticed increased expression of Cxcr4, Flk1 and Sox2 in the aggregate compared with MAPCs harvested from 2D surface culture. Cxcr4 is a receptor responsible for stem cell homing to stromal derived-factor 1 (SDF1) and is also up-regulated when human MSC are cultured as 3D 
aggregates (Potapova et al. 2008). We speculate that up-regulation of Flk1 may be due to hypoxic responsiveness of the cells within the aggregate, as has been observed in other systems (Purpura et al. 2008). It is interesting to see a modest up-regulation of Sox2, a transcription factor found in the ICM, epiblast and ESC as well as in NSC, in the MAPC aggregates (Rizzino 2009). In N2/B27 medium, MAPC express transcripts specific for neuroectoderm progenitors including Sox2 and Pax6 (UlloaMontoya et al. 2007). However, as no increase in expression of Pax6 was observed in the aggregates, an early commitment to the neuroectoderm lineage is unlikely. Upon cell dissociation of the aggregates and replating in 2D surface culture, the expression of Cxcr4, Flk1 and Sox2 transcripts returned to levels seen before 3D aggregate formation.

Importantly, to demonstrate that MAPCs in aggregates retained their potency, cells cultured as aggregates for sixteen days were tested for their ability to differentiate to the neuroectoderm, endothelial and hepatic lineage (Luttun et al. 2006; Ulloa-Montoya et al. 2007). Consistent with our finding that the phenotype of MAPC was unchanged when cultured in aggregates, the induction of lineage-specific transcripts was similar for cells dissociated from day 16-aggregate and the cells maintained in low-density 2D surface culture. Thus, we demonstrated that the cells in the aggregate still retained multi-lineage differentiation potential. However, as the cells derived from the aggregate were expanded for two passages in 2D to obtain enough cells for differentiation, the possibility exists that the differentiation seen is the result of a subfraction of cells that retained this ability and outgrew other cells that had lost differentiation potential. We therefore also assessed if differentiation to the hepatocyte-lineage could be obtained from the MAPC aggregates themselves, without replating onto 2D surface cultures. As the aggregates collected at different points of spinner culture (day 0,2 and 4) themselves could be differentiated to hepatocyte-like cells with similar levels of induction of hepatocyte specific transcripts as well as albumin and urea secretion rates, this strongly suggests that there was no progressive loss of potency of MAPCs during the four days of spinner culture as aggregates.

The culture platform described in this report allows for a 70-fold cell expansion of rat MAPCs (two MAPC lines) that retain the expression of MAPC markers at both mRNA and protein levels. Furthermore, this spinner expanded MAPC aggregates are capable of differentiating into 'hepatocytelike' cells. Stem cell derived 'hepatocyte-like' cells have applications in drug bioavailability and hepatoxicity evaluation studies, in bioartificial liver devices, and in cell therapies for a wide variety of liver disorders. Many of those applications require a large quantity of cells. Aggregate based suspension culture will facilitate cell expansion as well as mass differentiation of stem cells to hepatocytes. Extension of this platform for human stem cell cultivation will greatly facilitate potential clinical applications of stem cell derived hepatocytes. We envisage further studies of this and other similar culture platforms to lay the foundation of stem cell culture processes in the near future.

\section{ACKNOWLEDGEMENTS}

We thank Dr.Timothy O'Brien at Comparative Pathology Shared Resource, University of Minnesota, for E-Cadherin staining and Fang Zhou at the Characterization Facility, University of Minnesota for help with transmission electron microscopy. Kartik Subramanian was supported by the Doctoral dissertation fellowship, University of Minnesota. 


\section{REFERENCES}

1. Abranches E, Bekman E, Henrique D, Cabral JM. 2007. Expansion of mouse embryonic stem cells on microcarriers. Biotechnol Bioeng 96(6):1211-21.

2. Anjos-Afonso F, Bonnet D. 2007. Nonhematopoietic/endothelial SSEA-1+ cells define the most primitive progenitors in the adult murine bone marrow mesenchymal compartment. Blood 109(3):1298-306.

3. Beltrami AP, Cesselli D, Bergamin N, Marcon P, Rigo S, Puppato E, D'Aurizio F, Verardo R, Piazza S, Pignatelli A and others. 2007. Multipotent cells can be generated in vitro from several adult human organs (heart, liver, and bone marrow). Blood 110(9):3438-46.

4. Breyer A, Estharabadi N, Oki M, Ulloa F, Nelson-Holte M, Lien L, Jiang Y. 2006. Multipotent adult progenitor cell isolation and culture procedures. Exp Hematol 34(11):1596-601.

5. Cameron CM, Hu WS, Kaufman DS. 2006. Improved development of human embryonic stem cell-derived embryoid bodies by stirred vessel cultivation. Biotechnol Bioeng 94(5):938-48.

6. Cormier JT, zur Nieden NI, Rancourt DE, Kallos MS. 2006. Expansion of undifferentiated murine embryonic stem cells as aggregates in suspension culture bioreactors. Tissue Eng 12(11):3233-45.

7. D'Ippolito G, Diabira S, Howard GA, Menei P, Roos BA, Schiller PC. 2004. Marrow-isolated adult multilineage inducible (MIAMI) cells, a unique population of postnatal young and old human cells with extensive expansion and differentiation potential. J Cell Sci 117(Pt 14):297181.

8. D'Ippolito G, Diabira S, Howard GA, Roos BA, Schiller PC. 2006. Low oxygen tension inhibits osteogenic differentiation and enhances stemness of human MIAMI cells. Bone 39(3):513-22.

9. Dang SM, Gerecht-Nir S, Chen J, Itskovitz-Eldor J, Zandstra PW. 2004. Controlled, scalable embryonic stem cell differentiation culture. Stem Cells 22(3):275-82.

10. Debeb BG, Galat V, Epple-Farmer J, Iannaccone S, Woodward WA, Bader M, Iannaccone P, Binas B. 2009. Isolation of Oct4-expressing extraembryonic endoderm precursor cell lines. PLoS One 4(9):e7216.

11. Fok EY, Zandstra PW. 2005. Shear-controlled single-step mouse embryonic stem cell expansion and embryoid body-based differentiation. Stem Cells 23(9):1333-42.

12. Frauenschuh S, Reichmann E, Ibold Y, Goetz PM, Sittinger M, Ringe J. 2007. A microcarrierbased cultivation system for expansion of primary mesenchymal stem cells. Biotechnol Prog 23(1):187-93.

13. Frith JE, Thomson B, Genever P. 2009. Dynamic three-dimensional culture methods enhance mesenchymal stem cell properties and increase therapeutic potential. Tissue Eng Part C Methods.

14. Galat V, Binas B, Iannaccone S, Postovit LM, Debeb BG, Iannaccone P. 2009. Developmental potential of rat extraembryonic stem cells. Stem Cells Dev 18(9):1309-18.

15. Gilbertson JA, Sen A, Behie LA, Kallos MS. 2006. Scaled-up production of mammalian neural precursor cell aggregates in computer-controlled suspension bioreactors. Biotechnol Bioeng 94(4):783-92.

16. Grayson WL, Zhao F, Izadpanah R, Bunnell B, Ma T. 2006. Effects of hypoxia on human mesenchymal stem cell expansion and plasticity in 3D constructs. J Cell Physiol 207(2):331-9.

17. Griffith LG, Swartz MA. 2006. Capturing complex 3D tissue physiology in vitro. Nat Rev Mol Cell Biol 7(3):211-24. 
18. Guan K, Nayernia K, Maier LS, Wagner S, Dressel R, Lee JH, Nolte J, Wolf F, Li M, Engel W and others. 2006. Pluripotency of spermatogonial stem cells from adult mouse testis. Nature 440(7088):1199-203.

19. Gupta S, Verfaillie C, Chmielewski D, Kren S, Eidman K, Connaire J, Heremans Y, Lund T, Blackstad M, Jiang Y and others. 2006. Isolation and characterization of kidney-derived stem cells. J Am Soc Nephrol 17(11):3028-40.

20. Hevehan DL, Papoutsakis ET, Miller WM. 2000. Physiologically significant effects of $\mathrm{pH}$ and oxygen tension on granulopoiesis. Exp Hematol 28(3):267-75.

21. Javazon EH, Beggs KJ, Flake AW. 2004. Mesenchymal stem cells: paradoxes of passaging. Exp Hematol 32(5):414-25.

22. Jiang Y, Jahagirdar BN, Reinhardt RL, Schwartz RE, Keene CD, Ortiz-Gonzalez XR, Reyes M, Lenvik T, Lund T, Blackstad M and others. 2002. Pluripotency of mesenchymal stem cells derived from adult marrow. Nature 418(6893):41-9.

23. Kehoe DE, Jing D, Lock LT, Tzanakakis EM. 2009. Scalable Stirred-suspension Bioreactor Culture of Human Pluripotent Stem Cells. Tissue Eng Part A.

24. Keller PJ, Pampaloni F, Stelzer EH. 2006. Life sciences require the third dimension. Curr Opin Cell Biol 18(1):117-24.

25. Kelm JM, Timmins NE, Brown CJ, Fussenegger M, Nielsen LK. 2003. Method for generation of homogeneous multicellular tumor spheroids applicable to a wide variety of cell types. Biotechnol Bioeng 83(2):173-80.

26. King JA, Miller WM. 2007. Bioreactor development for stem cell expansion and controlled differentiation. Curr Opin Chem Biol 11(4):394-8.

27. Kirouac DC, Zandstra PW. 2008. The systematic production of cells for cell therapies. Cell Stem Cell 3(4):369-81.

28. Kogler G, Sensken S, Airey JA, Trapp T, Muschen M, Feldhahn N, Liedtke S, Sorg RV, Fischer J, Rosenbaum C and others. 2004. A new human somatic stem cell from placental cord blood with intrinsic pluripotent differentiation potential. J Exp Med 200(2):123-35.

29. Krawetz R, Taiani JT, Liu S, Meng G, Li X, Kallos MS, Rancourt D. 2009. Large-Scale Expansion of Pluripotent Human Embryonic Stem Cells in Stirred Suspension Bioreactors. Tissue Eng Part C Methods.

30. Kucia M, Reca R, Campbell FR, Zuba-Surma E, Majka M, Ratajczak J, Ratajczak MZ. 2006. A population of very small embryonic-like (VSEL) CXCR4(+)SSEA-1(+)Oct-4+ stem cells identified in adult bone marrow. Leukemia 20(5):857-69.

31. Kurosawa H. 2007. Methods for inducing embryoid body formation: in vitro differentiation system of embryonic stem cells. J Biosci Bioeng 103(5):389-98.

32. Kurosawa H, Imamura T, Koike M, Sasaki K, Amano Y. 2003. A simple method for forming embryoid body from mouse embryonic stem cells. J Biosci Bioeng 96(4):409-11.

33. Li Q, Liu Q, Cai H, Tan WS. 2006. A comparative gene-expression analysis of CD34+ hematopoietic stem and progenitor cells grown in static and stirred culture systems. Cell Mol Biol Lett 11(4):475-87.

34. Liu T, Zhang S, Chen X, Li G, Wang Y. 2009. Hepatic Differentiation of Mouse Embryonic Stem Cells in Three-dimensional Polymer Scaffolds. Tissue Eng Part A.

35. Lock LT, Tzanakakis ES. 2009. Expansion and differentiation of human embryonic stem cells to endoderm progeny in a microcarrier stirred-suspension culture. Tissue Eng Part A 15(8):2051-63.

36. Luttun A, Ross JJ, Verfaillie C, Aranguren XL, Prosper F. 2006. Differentiation of multipotent adult progenitor cells into functional endothelial and smooth muscle cells. Curr Protoc Immunol Chapter 22:Unit 22F 9. 
37. Mostafa SS, Miller WM, Papoutsakis ET. 2000. Oxygen tension influences the differentiation, maturation and apoptosis of human megakaryocytes. Br J Haematol 111(3):879-89.

38. Ng ES, Davis RP, Azzola L, Stanley EG, Elefanty AG. 2005. Forced aggregation of defined numbers of human embryonic stem cells into embryoid bodies fosters robust, reproducible hematopoietic differentiation. Blood 106(5):1601-3.

39. Niwa H. 2007. How is pluripotency determined and maintained? Development 134(4):635-46.

40. Oh SK, Chen AK, Mok Y, Chen X, Lim UM, Chin A, Choo AB, Reuveny S. 2009. Long-term microcarrier suspension cultures of human embryonic stem cells. Stem Cell Res.

41. Ong SM, Zhao Z, Arooz T, Zhao D, Zhang S, Du T, Wasser M, van Noort D, Yu H. 2009. Engineering a scaffold-free 3D tumor model for in vitro drug penetration studies. Biomaterials.

42. Pampaloni F, Reynaud EG, Stelzer EH. 2007. The third dimension bridges the gap between cell culture and live tissue. Nat Rev Mol Cell Biol 8(10):839-45.

43. Pochampally RR, Smith JR, Ylostalo J, Prockop DJ. 2004. Serum deprivation of human marrow stromal cells (hMSCs) selects for a subpopulation of early progenitor cells with enhanced expression of OCT-4 and other embryonic genes. Blood 103(5):1647-52.

44. Potapova IA, Brink PR, Cohen IS, Doronin SV. 2008. Culturing of Human Mesenchymal Stem Cells as Three-dimensional Aggregates Induces Functional Expression of CXCR4 That Regulates Adhesion to Endothelial Cells. J Biol Chem 283(19):13100-7.

45. Purpura KA, George SH, Dang SM, Choi K, Nagy A, Zandstra PW. 2008. Soluble Flt-1 regulates Flk-1 activation to control hematopoietic and endothelial development in an oxygenresponsive manner. Stem Cells 26(11):2832-42.

46. Ralston A, Rossant J. 2005. Genetic regulation of stem cell origins in the mouse embryo. Clin Genet 68(2):106-12.

47. Ratajczak MZ, Zuba-Surma EK, Wysoczynski M, Ratajczak J, Kucia M. 2008. Very small embryonic-like stem cells: characterization, developmental origin, and biological significance. Exp Hematol 36(6):742-51.

48. Reyes M, Lund T, Lenvik T, Aguiar D, Koodie L, Verfaillie CM. 2001. Purification and ex vivo expansion of postnatal human marrow mesodermal progenitor cells. Blood 98(9):2615-25.

49. Rizzino A. 2009. Sox2 and Oct-3/4: A Versatile Pair of Master Regulators that Orchestrate the Self-renewal and Pluripotency of Embryonic Stem Cells by Functioning as Molecular Rheostats. Wiley Interdiscip Rev Syst Biol Med 1(2):228-236.

50. Sancho-Bru P, Najimi M, Caruso M, Pauwelyn K, Cantz T, Forbes S, Roskams T, Ott M, Gehling U, Sokal E and others. 2009. Stem and progenitor cells for liver repopulation: can we standardise the process from bench to bedside? Gut 58(4):594-603.

51. Schwartz RE, Reyes M, Koodie L, Jiang Y, Blackstad M, Lund T, Lenvik T, Johnson S, Hu WS, Verfaillie CM. 2002. Multipotent adult progenitor cells from bone marrow differentiate into functional hepatocyte-like cells. J Clin Invest 109(10):1291-302.

52. Subramanian K, Geraerts M, Pauwelyn KA, Park Y, Owens DJ, Muijtjens M, Ulloa-Montoya $\mathrm{F}$, Jiang Y, Verfaillie CM, Hu WS. Isolation procedure and characterization of multipotent adult progenitor cells from rat bone marrow. Methods Mol Biol 636:55-78.

53. Ulloa-Montoya F, Kidder BL, Pauwelyn KA, Chase LG, Luttun A, Crabbe A, Geraerts M, Sharov AA, Piao Y, Ko MS and others. 2007. Comparative transcriptome analysis of embryonic and adult stem cells with extended and limited differentiation capacity. Genome Biol 8(8):R163.

54. Yamada KM, Cukierman E. 2007. Modeling tissue morphogenesis and cancer in 3D. Cell 130(4):601-10. 
55. Yoon YS, Wecker A, Heyd L, Park JS, Tkebuchava T, Kusano K, Hanley A, Scadova H, Qin G, Cha DH and others. 2005. Clonally expanded novel multipotent stem cells from human bone marrow regenerate myocardium after myocardial infarction. J Clin Invest 115(2):326-38.

56. Yu Y, Li K, Bao C, Liu T, Jin Y, Ren H, Yun W. 2009. Ex vitro expansion of human placentaderived mesenchymal stem cells in stirred bioreactor. Appl Biochem Biotechnol 159(1):110-8.

57. Zhao F, Ma T. 2005. Perfusion bioreactor system for human mesenchymal stem cell tissue engineering: dynamic cell seeding and construct development. Biotechnol Bioeng 91(4):48293.

58. zur Nieden NI, Cormier JT, Rancourt DE, Kallos MS. 2007. Embryonic stem cells remain highly pluripotent following long term expansion as aggregates in suspension bioreactors. $\mathrm{J}$ Biotechnol 129(3):421-32.

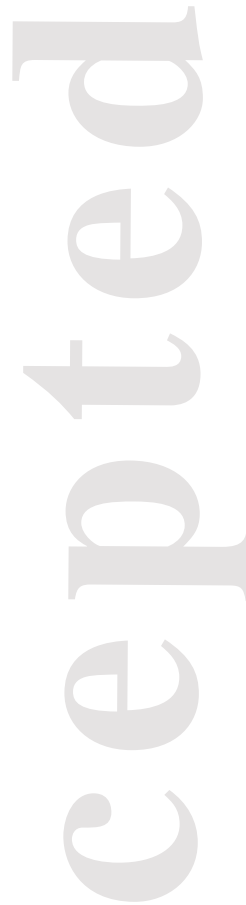

FIGURE LEGENDS 
Figure 1. Aggregates retain MAPC phenotype. (a) Transcript level of pluripotency, primitive endoderm and differentiation markers of surface cultured ( $\square / \mathbf{\square})$ and aggregates (Day $4, \boldsymbol{\square} / \mathbf{\square})$ of MAPC (Data of 2 lines are shown for each). (b) Flow cytometric measurement of Oct4 protein in aggregates and surface cultured MAPC (negative isotype control and Oct4 antibody treated samples are shown in both cases) (c) Transcript level of Oct4 (ם) and AFP (घ), and (d) Flow cytometric measurement of Oct4 in aggregates formed in $21 \%$ oxygen or in differentiation inducing conditions (negative isotype control and Oct4 antibody treated samples are shown in red and blue respectively).

Figure 2. Characterization of MAPC aggregates a) Morphology of MAPC aggregates (Day 4), (scale bar $200 \mu \mathrm{m}$ ) (b) Change in aggregate size during the first $48 \mathrm{hr}$ of aggregate formation (c) Cell proliferation during aggregate formation e) TEM section of MAPC aggregate (d) E-cadherin staining.

Figure 3. Static Culture of MAPC aggregates: Change of (a) Oct4 and (b) AFP transcript levels in 16 day culture of $(\boldsymbol{\square} / \square)$ aggregate culture; $(\Delta / \Delta)$ aggregate in differentiation medium. Black and white symbols represent the different MAPC lines (c), (d) Flow cytometric measurement of Oct4 in MAPC aggregates on Day 16 in the two rat MAPC lines (negative isotype control and Oct4 antibody treated samples are shown in red and blue respectively)

Figure 4. Directed differentiation of aggregate derived MAPC (Day 16) (a) Transcript levels of neural progenitor markers Sox2, Nestin, Pax6 in neural differentiation (b) Transcript levels of endothelial markers Flk-1, Ve-Cadherin, $v W F$, enos in endothelial differentiation (c) Transcript expression of hepatocyte markers AFP, Albumin, AAT, TAT in hepatocyte differentiation ( $\square / \mathbf{a})$ : surface culture ( $\mathbf{\square} / \mathbf{n})$ : day 16 aggregate derived cells (Data from two different cell lines are shown for each, mean of $n=3$ differentiations)

Figure 5. Expansion of MAPC cell aggregates in spinner flasks (a) Cell proliferation profile (b) Vital stain of MAPC aggregates (Day 4) (c) Transcript level of MAPC markers ( $\mathbf{a}) \operatorname{Oct} 4 ;(\boldsymbol{\Delta}) \operatorname{Rex} 1 ;(\mathrm{x})$ $C D 31 ; \bullet)$ Sall4; $\bullet) A F P$ (average of three spinner flask runs) (d) Flow cytometric measurement of Oct4 in MAPC aggregates at the end of spinner culture (day 4) and in control 2D culture (day4) (negative isotype control and Oct4 antibody treated samples are shown in red and blue respectively) (e) Transcript level of hepatocyte markers in hepatocyte differentiation conditions in static culture starting

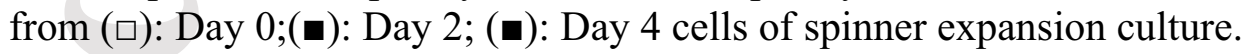

\section{Supplementary Figures}

S1. Transcript level of MAPC/primitive endoderm markers ( $\square$ ): surface culture (ם): MAPC cell aggregate in static culture and ( $\mathbf{\varpi})$ : MAPC cell aggregate in suspension culture

S2. a) Transcript level of fibronectin in surface culture (2D MAPCs), cell aggregate (3D MAPCs) and rat universal mRNA b) Growth of MAPCs on fibronectin or aggregate culture conditioned medium (3D CM) or surface culture conditioned medium (2D CM) coated plates or without coating

S3. Replating of MAPC aggregates a) Transcript level of pluripotency and differentiation markers in surface cultured (口), aggregates (Day 4, 口) and replated surface culture of aggregate derived cells (passage 2, a) of MAPCs b) Morphology of surface cultured MAPCs c) Morphology of replated surface culture of aggregate derived cells

S4. Cell cycle distribution in surface culture of MAPCs ( $\square$ ) and MAPC aggregates (Day 4, $\mathbf{\square})$ in maintenance medium, surface culture of MAPCs in differentiation medium (DM, $\mathbf{n})$

S5. Morphology of MAPC aggregates on day 10 of static culture to demonstrate the beginning of budding of a small group of cells from each cell aggregate

S6. Expansion of MAPC aggregates in spinner flask for another rat MAPC line (a) Cell proliferation profile for two expansion runs (b) Transcript level of MAPC markers on MAPC aggregates (Day 0, $\square$; Day 4 Run 1, घ; Day 4 Run 2, a) (c) Flow cytometric measurement of Oct4 in MAPC aggregates on Day 4 (negative isotype control and Oct4 antibody treated samples are shown in red and blue respectively) 
a)
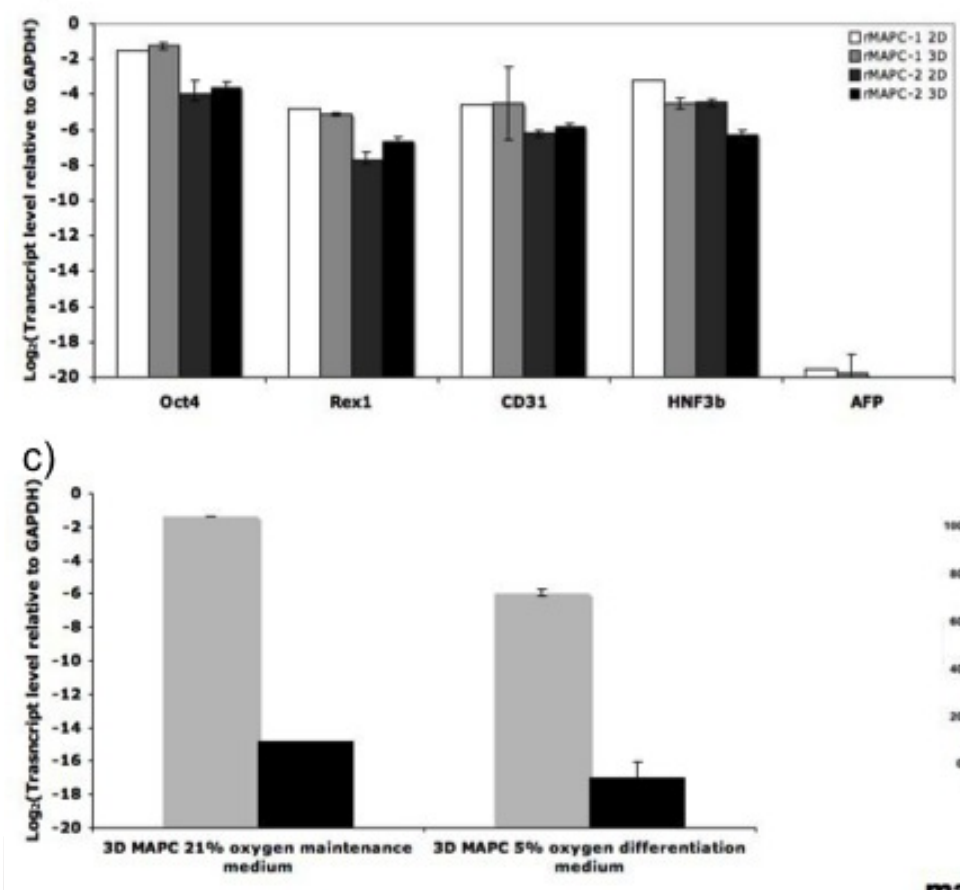

Figure 1. b)

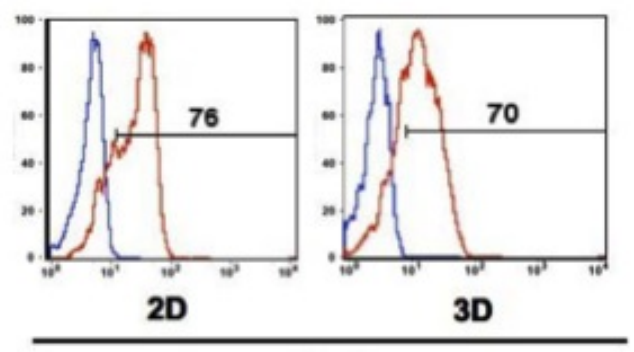

$5 \% \mathrm{O}_{2}$

d)

maintenance medium
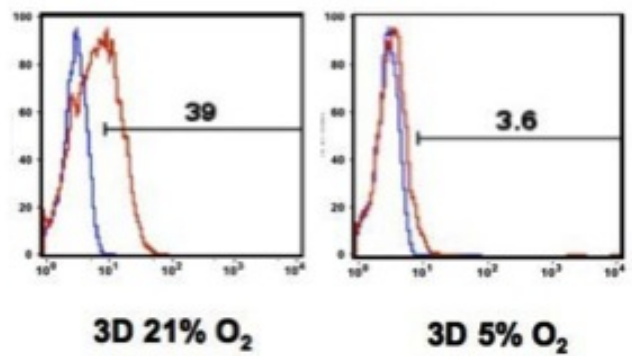

maintenance medium differentiation medium 
a)

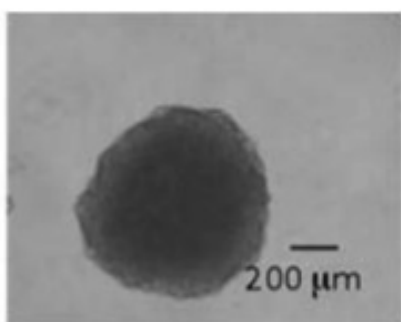

c)

C) 30000 卷 20000

중 15000 空 10000 5000 0

d)

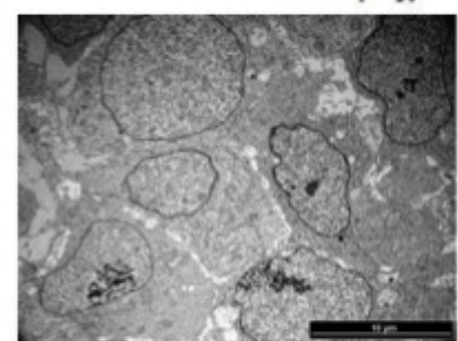

b)

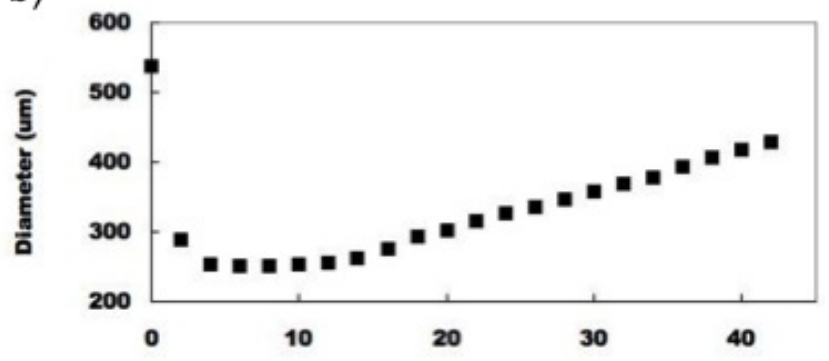

Time (hour)

e)

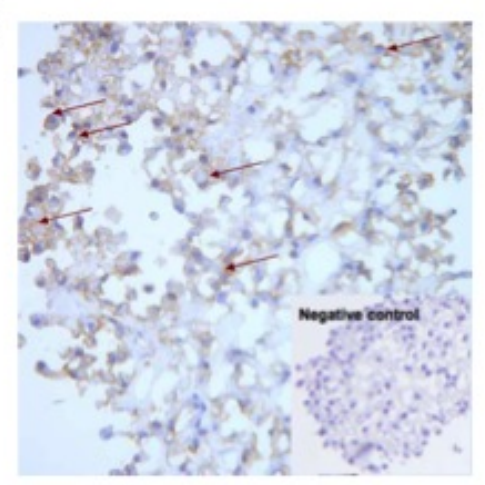

Figure 2. 
a)

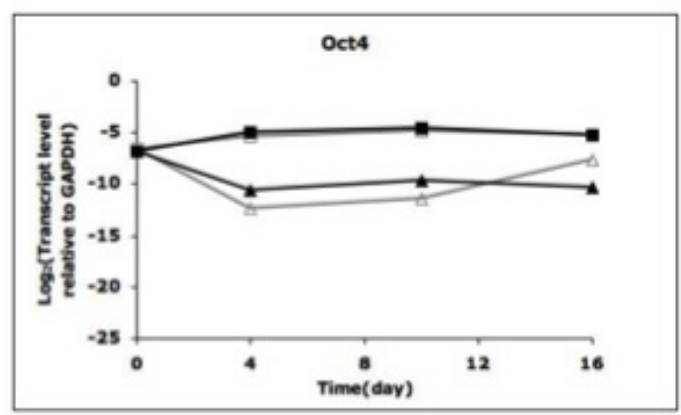

c)

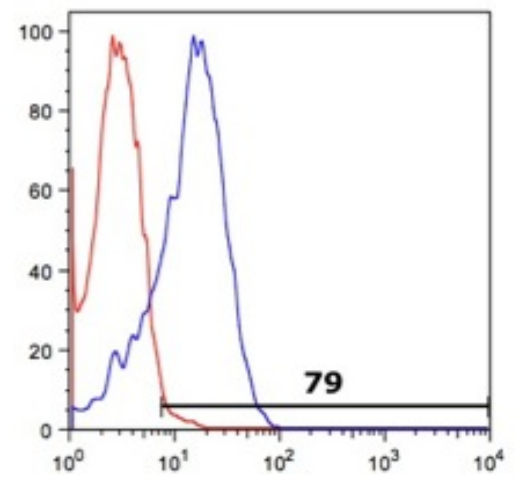

b)

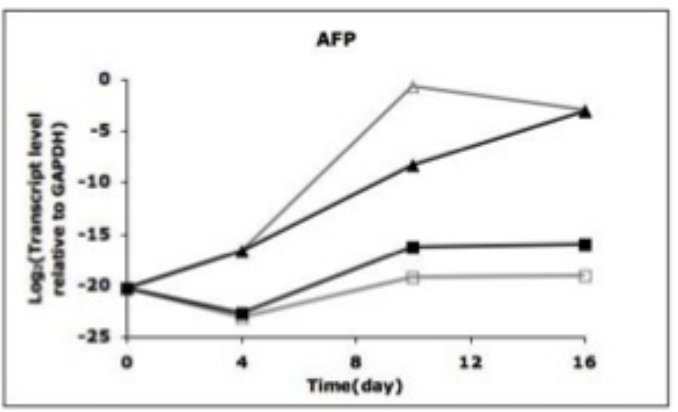

d)

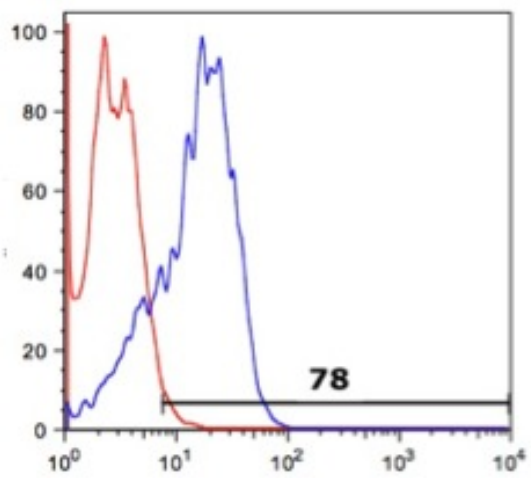

Figure 3. 
a)

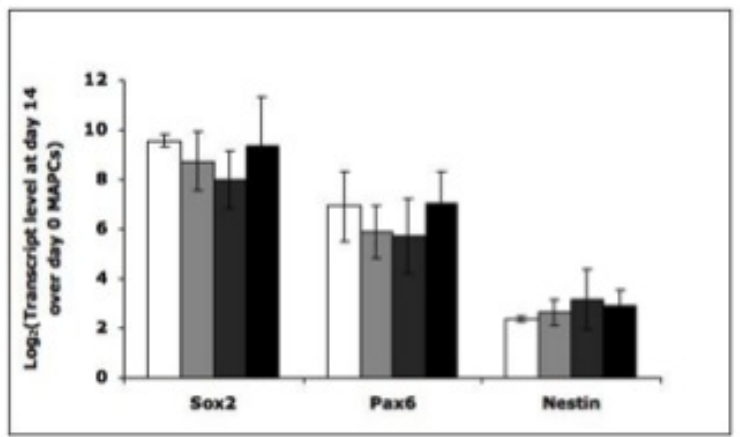

c)

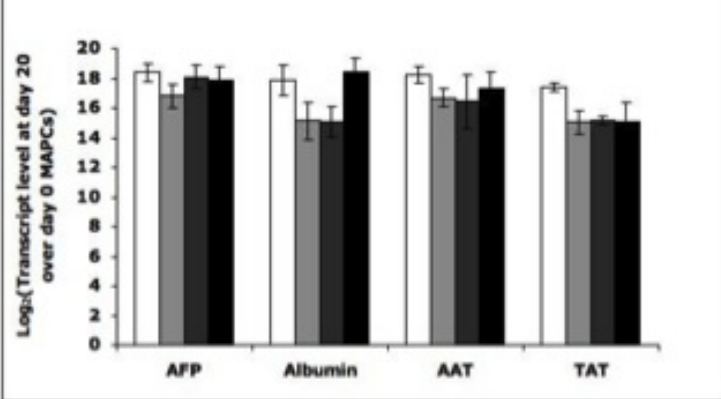

b)

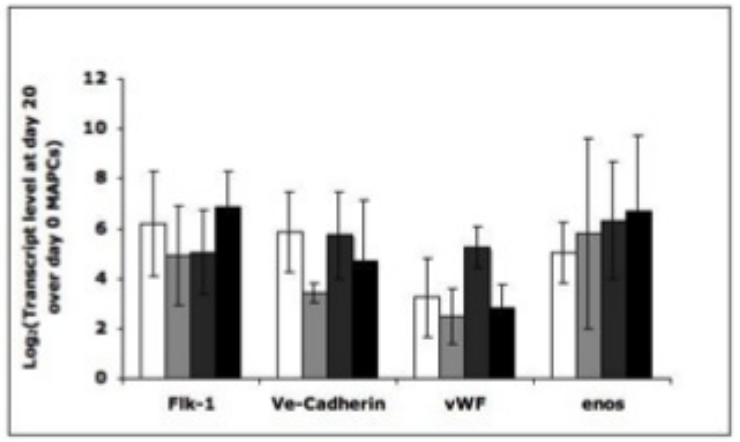

Figure 4. 
a)

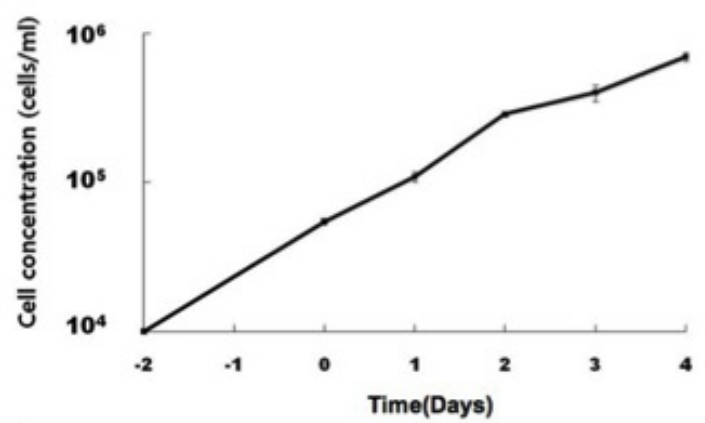

c)

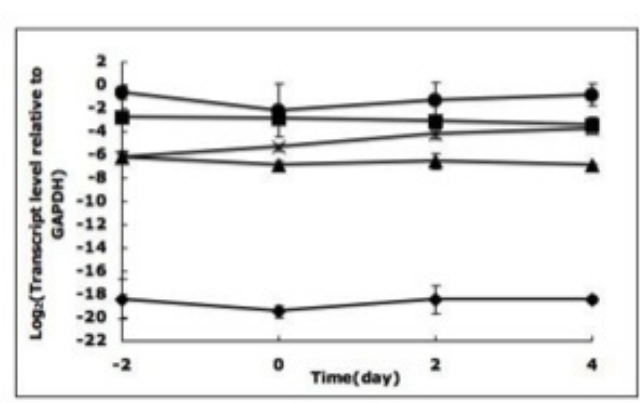

e)

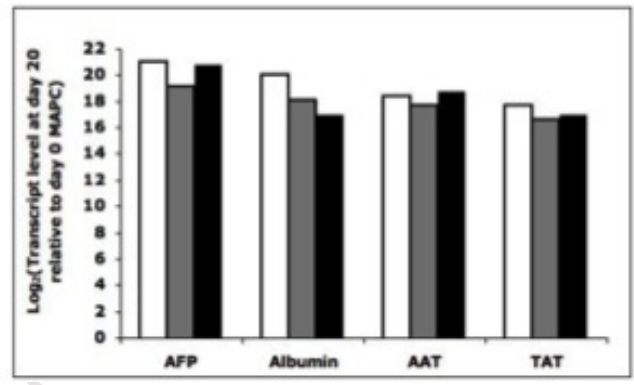

b)

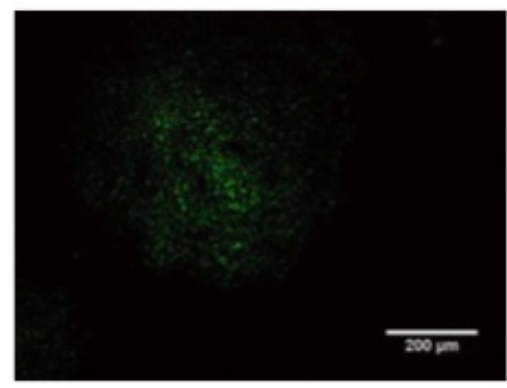

d)

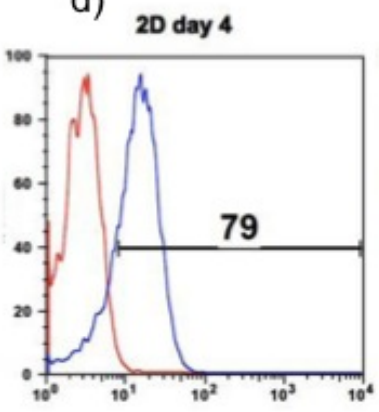

3D spinner flask day 4

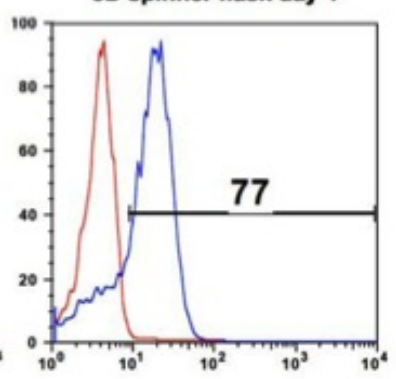

Figure 5. 
TABLE 1: LIST OF PRIMERS FOR PCR

\begin{tabular}{|c|c|c|c|}
\hline Cell Lineage & Gene & Forward Primer & Reverse Primer \\
\hline ing & Gapdh & AAGGGCTCATGACCACAGTC & GGATGCAGGCATGATGTTCT \\
\hline \multirow{9}{*}{$\begin{array}{l}\text { Pluripotency } \\
\text { /MAPC }\end{array}$} & Oct4 & CTGTAACCGGCGCCAGAA & TGCATGGGAGAGCCCAGA \\
\hline & Rex1 & AAAGCTTTTACAGAGAGCTCGAAACTA & GTGCGCAAGTTGAAATCCAGT \\
\hline & Sall4 & AGAACTTCTCGTCTGCCAGTG & CTCTATGGCCAGCTTCCTTC \\
\hline & CD31 & GGACTGGCCCTGTCACGTT & TTGTTCATGGTGCCAAAACACT \\
\hline & HNF3b & GCAGAACTCCATCCGTCATT & TCGAACATGTTGCCAGAGTC \\
\hline & GATA4 & CTGTGCCAACTGCCAGACTA & AGATTCTTGGGCTTCCGTTT \\
\hline & GATA6 & GTCTGGATGGAGCCACAGTT & ATCATCACCACCCGACCTAC \\
\hline & sox7 & CAAGGATGAGAGGAAACGTC & СTCTGCCTCATCCACATAGG \\
\hline & SOX17 & GCCAAAGACGAACGCAAGCGG & TCATGCGCTTCACCTGCTTG \\
\hline \multirow[t]{4}{*}{ Hepatic lineage } & AFP & ACCTGACAGGGAAGATGGTG & GCAGTGGTTGATACCGGAGT \\
\hline & Albumin & TCTGCACACTCCCAGACAAG & AGTCACCCATCACCGTCTTC \\
\hline & AAT & CAAACAAGGTCAGCCATTCTC & CAGCATCATTGTTGAAGACCC \\
\hline & TAT & GGAAGCTAAGGATGTCATTCTG & GACCTCAATTCCCATAGACTC \\
\hline \multirow[t]{4}{*}{ Endothelium } & Flk-1 & CCAAGCTCAGCACACAAAAA & CCAACCACTCTGGGAACTGT \\
\hline & $\begin{array}{l}\text { Ve- } \\
\text { Cadherin }\end{array}$ & GGCCAACGAATTGGATTCTA & GTTTACTGGCACCACGTCCT \\
\hline & vWF & CCCACCGGATGGCTAGGTATT & GAGGCGGATCTGTTTGAGGTT \\
\hline & enos & TCCAGTAACACAGACAGTGCA & CAGGAAGTAAGTGAGAGC \\
\hline \multirow[t]{3}{*}{ Neuroectoderm } & Sox2 & GGCCAACGAATTGGATTCTA & GTTTACTGGCACCACGTCCT \\
\hline & Pax6 & GTCCATCTTTGCTTGGGAAA & TAGCCAGGTTGCGAAGAACT \\
\hline & Nestin & CCCCAGAAACAGAAGAAGATGAG & CATGGGCATCTGTCAGGATTG \\
\hline
\end{tabular}

